\title{
On the Divergence of a Proto-Indo-European Velar Syllabic Nasal in Indo-European Languages
}

\author{
Georgiy M. Telezhko \\ Sole Proprietorship \\ yurate@bk.ru
}

Introduction. The proposed article critically examines the explanation of the origin of nasal vowels in Slavic languages by incorporating an open syllable law. It is shown that the convergence of many closed syllables, ending with nasal consonants, into two kinds of open syllables with nasal vowels contradicts a number of facts of evolution in the opposite direction, e.g., evolution of nasal vowels towards combinations "a vowel - a nasal consonant" in Balkan Slavic languages (Bulg. пент "five", вънзел "knot"), as well as to the observed interpretation of Slavic nasal vowels in acts of borrowing by languages without nasal vowels, e. g. OCS джбрава "oak forest" > Rom. dumbrávă.

Methodology and sources. The proposed model results from generalization of the data of instrumental phonetical research, which show that the articulation of palatal consonants is unstable leading to there divergent evolution, i. e. transformation to sounds with more definite zones of articulation, e.g. palatal lateral approximant ${ }^{*}[\Lambda]$ split into palatalized lateral liquid [l'] and fricative [j].

In the proposed model Proto-Indo-European (PIE) syllable velar nasal consonant * $\eta$ ' in the process of its phonetic evolution in Indo-European (IE) languages split into a variety of nasal vowels with different articulations, which further on irregularly transformed into vowels without nasalization or into combinations of vowels with nasal consonants (e.g. Olnd. panktís, OIsl. fimt, Lith. penkì, OCS пıтьь, OHG finf, fimf, funf "пять", etc., from the common PIE prototype with syllable nasal * $\left.{ }^{*}\right)$.

Results and discussion. Examples of PIE prototypes of lexemes meaning "water bird", "tooth, sharp edge", "five", as well as lexemes, related to Russ. нутро, ядро, неясыть, уж, угорь, нагой, нога, ноготь are presented. All prototypes contain a nasal syllabic, which is split producing four types of reflexes in IE languages. Newly discovered etymological links, such as the connection between Russ. Lexemes meaning "leg" and "corner", are discussed.

Conclusion. The proposed model permits to uniformly explain the facts of synchronous existence of related Rus. недро "insides" and ядро "nucleos", related нутро и утроба "belly", related OCS жты, Lith. ántis and AGr. Att. vñtтa "duck", related Rus. неясыть "a kind of owl; pelican" and ненасытный "insatiable", etc., using the notion of divergent evolution of the PIE syllable velar nasal *n'.

Keywords: velar syllabic nasal, nasal vowels, divergence, diphthong-like combinations, articulation.

For citation: Telezhko G. M. On the Divergence of a Proto-Indo-European Velar Syllabic Nasal in IndoEuropean Languages. DISCOURSE. 2019, vol. 5, no. 5, pp. 114-122. DOI: 10.32603/2412-8562-2019-55-114-122

Conflict of interest. No conflicts of interest related to this publication were reported. 


\title{
О дивергенции праиндоевропейского велярного слогового носового согласного в индоевропейских языках
}

\author{
Г. М. Тележкко \\ Индивидуальный предприниматель \\ 凶yurate@bk.ru
}

\begin{abstract}
Введение. В предлагаемой статье критически рассматривается объяснение происхождения носовых гласных в славянских языках с помощью включения закона открытого слога. Показано, что происходящая при этом конвергенция множества закрытых слогов, заканчивающихся на носовые согласные, в два вида открытых слогов с носовыми гласными противоречит ряду фактов эволюции в обратном направлении, например, эволюции носовых гласных в сочетаниях "гласный - носовой согласный" в балкано-славянских языках (болг. пент "пять", вънзел "узел"), а также наблюдаемой передаче носовых гласных при заимствовании славянских слов с носовыми гласными в языки, в которых носовые гласные отсутствовали, например, ст.-слав. джбрава "дубовый лес" > рум. dumbrávă.

Методология и источники. Предлагается модель, построенная на основе обобщения результатов инструментальных исследований, показавших, что палатальные звуки характеризуются неустойчивостью артикуляции. Это приводит к их дивергентному развитию, преобразованию в звуки с различными устойчивыми зонами артикуляции, например, известно расщепление палатального бокового аппроксиманта *[ᄉ] на палатализованный боковой плавный [l'] и фрикативный [j]. В предлагаемой модели праиндоевропейский (ПИЕ) слоговый велярный носовой согласный *'ं в процессе фонетической эволюции в индоевропейских (ИЕ) языках расщеплялся на варианты носовых гласных с различной артикуляцией, которые при дальнейшем развитии нерегулярно переходили в гласные без назализации или в сочетания гласных с носовыми согласными (напр. др.-инд. pajktíș, др.-исл. fimt, лит. penkì, ст.-слав. пюАть, д.-в.-н. finf, fimf, funf "пять" и др. из общего ПИЕ прототипа с носовым слоговым *').
\end{abstract}

Результаты и обсуждение. Приведены примеры ПИЕ прототипов лексем со значениями "водная птица", "зуб, острая кромка", "пять", а также лексем, родственных рус. нутро, ядро, неясыть, уж, угорь, нагой, нога, ноготь. Все прототипы содержат носовой слоговый *';', который расщеплялся с образованием четырёх видов рефлексов в ИЕ языках. Обсуждаются вновь обнаруженные этимологические связи, например, связи между рус. лексемами со значениями "нога" и "угол".

Заключение. С помощью механизма дивергентного развития слогового велярного носового ``' единообразно объясняются факты одновременного существования родственных рус. недро и ядро, родственных нутро и утроба, родственных ст.-слав.

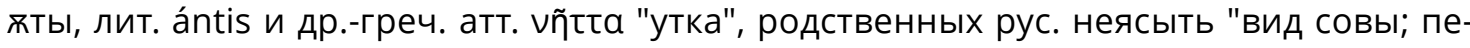
ликан" и ненасытный, и т. д.

Для цитирования: Тележко Г. М. О дивергенции праиндоевропейского велярного слогового носового согласного в индоевропейских языках // ДИСКУРС. 2019. Т. 5, № 5. С. 114-122. DOІ: 10.32603/2412-8562-2019-5-5-114-122

Конфликт интересов. О конфликте интересов, связанном с данной публикацией, не сообщалось.

Поступила 26.08.2019; принята после рецензирования 24.09.2019; опубликована онлайн 25.11.2019

Introduction. It is widely accepted that Proto-Slavic diphthong-like combinations of vowels and nasal consonants, i. e. combinations $V N$ succeeded by a consonant (not nasal), where $V$ is a vowel, $N$ is a nasal consonant, should have turned into monophthongs due to the Open Syllables Law. This general formula implies multiple convergent transformations: 
- reduction of the nasal consonant and its articulational merge with the preceding vowel had taken place in combinations $*_{o n}, *_{o m}, *_{a n}, *_{a m}$ (and in some cases, $*_{u n}>^{*} *_{n}, *_{u m}>^{*} *_{m}$ ) in the position before consonants (but nasals), and thus the nasal vowel * $g$ emerged;

- reduction of the nasal consonant and its articulational merge with the preceding vowel had taken place in combinations $*_{e n},{ }^{*} e m,{ }^{*} i n>{ }_{b n},{ }^{*} i m>*_{b m}$ in the position before consonants (but nasals), and thus the nasal vowel $*_{e}$ emerged.

The phenomenon of convergence of ${ }^{*} o n,{ }^{*} a n$ to ${ }^{*} g$ is being explained by shortening of the vowels in the syllables [1, p. 204].

The existing model of the genesis of nasal vowels in Slavic languages seemingly does not match the trend toward divergent evolution to more certain sounds: in the accepted model more definite PIE combinations of vowels and nasal consonants temporarily evolved into a small number of nasal vowels with unclear articulation.

Methodology and sources. The goal of the present article is to demonstrate that the thesis about divergent evolution of uncertain ancient sounds is applicable to the evolution of nasals and combinations including nasals. IE lexemes, further used as examples, have been cross-checked using different web dictionaries [2-9].

Instrumental phonetical research shows that the articulation of palatal consonants is unstable and can be described as palatal, palato-alveolar, postalveolar etc. [10, p. 22]. For example, the instability of the place of articulation makes the palatal consonant $[\Lambda]$ to change its articulation area to a more stable location: either to alveoli thus producing [l'], or backwards thus producing fricative [j].

The suggested solution results from generalization of this phenomenon.

In previous articles we have shown that the uncertainty of articulation (a wide range of possible articulations) led eventually to their almost irregular divergent evolution, producing more definite variants of pronunciation, e. g.:

- palatal lateral approximant $*[K]$ split into [j], [K] и [1] (ORuss. бояринъ, Serb. бољарин, OCS больринъ) [11];

- voiced velarized lateral approximant *[1] split into [0], [w], [1] и [1] (Goth. sunnô, Tokh. swāanc-, Pol. stońce, OCS сльньие) [12];

- syllable liquid [r/li $\left.{ }_{0}\right]$ between consonants or before a consonant split into $[\mathrm{r} / \mathrm{l}],[\mathrm{Vr} / \mathrm{Vl}]$, [rV/lV], [VrV/VlV] (OInd. ŕśya-, Lat. alcēs, ORuss. лось, OHG elaho) [13].

It is worth mentioning that the articulation of nasal vowels is said to be rather uncertain as well [1, p. 241], [14, p. 42-44], [15, p. 49], [16, p. 237, 238].

The above-mentioned instability of articulation of nasal vowels led to their transformation into pure vowels with more determined articulation in the majority of Slavic languages. And sometimes they surprisingly turned into combinations of vowels with nasal consonants which are believed to be the source IE combinations: Bulg. пент [pent] "five", вънзел [vәnzel] "knot" [17, p. 72].

Slavic nasal vowels had been changed the same way when being borrowed into languages having no nasal vowels at the time of borrowing. They were interpreted as simplified combinations "pure vowel - nasal consonant", e. g.:

- OCS джбрава "oak forest" > Rom. dumbrávă (caută: dumbravă [6]);

- OCS $c$ $\not z$ "court" > Est. sund;

- OCS сждии "judge" > Fin. suntio "church attendant";

- OCS кждглль "tow" > kuontalo; 
- OCS $ж \partial a$ "fishing rod" > эст. und.

The same way Slavic names with nasal vowels had been interpreted: Constantine Porphyrogenitus referred to Slavic names Сватославъ and *Motimirb as $\Sigma \varphi \varepsilon v \delta о \sigma \theta \lambda \alpha \dot{\beta} \beta о \varsigma$ and

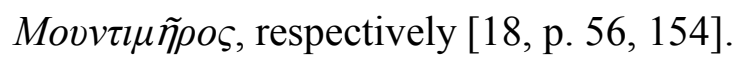

The direction of nasal vowel transformations clearly followed the principle of raising of the certainty of articulation while borrowing. It is natural to expect that the evolution of the primordial nasal vowels should have followed the same principle, i.e. that they tended to transform into combinations of vowels with nasal consonants. This gives the reason to suggest prototypes with nasal vowels for such combinations, when they are followed by consonants, not vice versa.

According to A. Meillet, these combinations resulted from PIE syllable nasals directly:

$n>$ Lith. in, un, Lat. $n a$, Goth. un;

$m>$ Lith. im, um, Lat. ma, Goth. um [19, c. 94].

This suggestion does not explain oscillations $[\mathrm{n}] \sim[\mathrm{m}]$ in closely related languages, in that number, e.g. OInd. nagnás Avest. mayna- "naked".

Syllable velar nasal $*[\dot{y}]$ looks more preferable as a PIE prototype. On the one hand, this consonant demands less articulatonal effort than other nasal consonants, hence the sound looks more suitable for ancient speakers. On the other hand, uncertainty of its articulation lets it be split into more clear forms during phonetic evolution, which could explain the later oscillations [n] $[\mathrm{m}]$, in particular.

Co-existence of the articulational delay of nasality in Polish nasal vowels and the absence of such delay in the articulation of French nasal vowels also witness the splitting of some nasal sound - their common source.

Combinations of vowels with nasal consonants succeeded by consonants are similar to combinations of vowels with liquid consonants in the same position ( $V r T, r V T$, etc.) [13]. This analogy and the priority of nasal vowels in relation to combinations of vowels with nasal consonants prompt that the various $V N$ combinations could have resulted also almost irregularly from vowels with delayed nasality, which, in their turn, had resulted from splitting of PIE syllable nasal *[i่].

Generalizing this suggestion, we come to the conclusion that the reflexes of PIE syllable *[j] in IE languages, at first approximation, are as follows:

a) "pure" nasal vowels, as in French;

b) evolving vowels with delayed nasality $*\left[\mathrm{~V}^{\mathrm{\eta}}\right]>[\mathrm{VN}]$;

c) evolving vowels with preceding nasality $*\left[{ }^{(\mathrm{V}) \mathrm{n}} \mathrm{V}\right]>[(\mathrm{V}) \mathrm{NV}]$;

d) vowels without nasality (most probable, this reflex is the result of evolution of the abovementioned reflexes, therefore we will not consider this reflex in detail).

Results and discussion. Examples of PIE prototypes with syllable nasal *[í] and their reflexes:

- *jंt- "water bird" (replacing the prototypes suggested in [4]: *anət-, *nāt-):

a) * $q t$ - > $o^{\eta} t->$ OCS $\kappa m$-bl, Sloven. ột-va "duck", further on to the reflex $d$ ): ORuss. $y m-b l$, Russ. ym-uнbiü, etc.;

$b) * a^{\eta} t->$ Lith. ánt-is "duck"; further on $\left.b\right)>d$ ): OInd. āt-ís "water bird";

c) ${ }^{*(V) \eta} V t->$ AGr. Att. $v \tilde{\eta} \tau-\tau \alpha$, AGr. $v \tilde{\eta} \sigma-\sigma \alpha$, AGr. Beot. $v \tilde{\alpha} \sigma-\sigma \alpha$; Lat. anas, gen. anat-is, anatinus "duck's", OHG anut "duck";

- * $\forall \dot{y} b^{h}$ - "tooth, sharp edge": 
a) *zob-/*zęb- > OCS зжб-ъ, Pol. ząb, gen. zęb-u; OCS знаб-ж "I'm cold", Pol. zięb-nać, further on to the reflex $d$ ): ORuss. зуб-ъ, Russ. зяб-ну, Bulg. зе́б-на и т. п.;

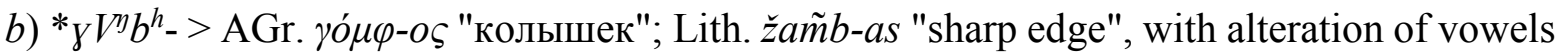
- Lith. žem $b$ - $t i$ "to slit", further on to the reflex $d$ ): Lett. $z o \dot{o} b-s$;

c) ${ }_{z} \eta^{V} b$ - > Russ. зноб-ить, probably, зно-й "heat", зне-(я)mь "to smolder" (without formant $-b$ - from PIE -bhos, which makes the second stem in the PIE lexeme for "tooth", according to O. Trubachyov, see his commentary to the article "зуб" in [5]);

- *pij $k^{n}$ - "five" ([M] - voiceless bilabial approximant):

a) *pęt-/pqt-> OCS ntamb, Sloven. pệt "five", Polab. pąt, further on to ORuss. nam-b, etc.;

b): ${ }^{*} p V^{\eta} k^{n}->$ AGr. $\pi \dot{v} v \varepsilon \varepsilon$, AGr. Aeol. $\pi \varepsilon ́ \mu \pi \varepsilon$; OInd. páñca; Lith. penki, further on $\left.b\right)>d$ ): Lett. pieci; dial. OHG fimf, finf, funf "five" (Meaning: five [4]) - these are the results of different attempts of approximation of the original combination * $V^{\eta}$, namely, en, em, im, in and un, further on to the reflex $d$ ): O. Sax. fif, etc.

c) ${ }^{*} p^{(V)} \eta^{V} k^{\mu}$ - - this reflex had not been realized in lexemes with the meaning "five" (but $* p^{(V)} \eta^{V}$ - can be numerously seen in lexemes related to OCS nнsmu "pull" (e. g. in OCS опона, Gr. $\pi \dot{v} v o \mu \alpha l$ ) which is related to OCS $n_{L A} m b$ "five").

Lexemes including the reflex $c$ ) usually have vague etymologies, hence we think that consideration of some more of its examples might be useful.

Lexemes related to Russ. ядро.

For example, in order to explain the simultaneous existence of etymologically related forms недро and ядро in Russian, a combination of several assumptions was needed (articles "недро" and "ядро" in [5]):

- one could assume the reconstruction *ědra, which would evolve to Proto-Slavic *jadra;

- Proto-Slavic *nědro could come from vъnědrěxъ, pl. locat., vъnědra, pl. acc. as a result of reinterpretation of $v ъ n+\check{e} d r$ - as $v ъ+n e ̌ d r-$.

As in the previously considered examples, we suggest for this case the typical evolution of the original $*[\dot{y}]$ :

a) *[j] $>*[j o] / *[j e]-$ OCS in initial position), further on to ORuss. Iaдpo "fruit";

b) *[门่] > [VN] - Skr. āṇdám, OInd. aṇ̣̂ás "egg", aṇdám "testicle ";

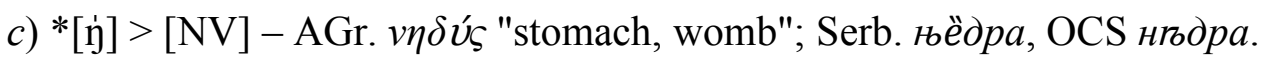

Lexemes related to Russ. нyтро.

Relations between Russ. утроба и нутро are explained similarly: *vъn-Qtrb "into", was interpreted as *vb-notrb (article "нутро" in [5]). We, contrary to Vasmer again (and to Baudouin de Courtenay), suggest divergent evolution of PIE preposition / prefix * $(w / j) \dot{y}->*(w / j) q^{-} / *(w / j) e-[20]$ :

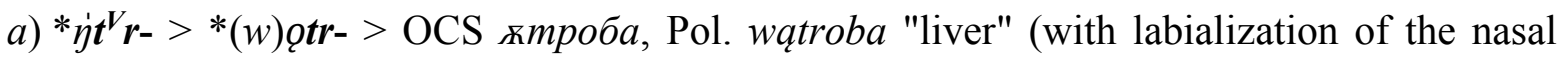
vowel in initial position), further on to ORuss. утроба, etc.; and (with iotization of nasal vowels in initial position and alteration of nasals, *jotr-/*jętr-: Russ. Ch. Slav. ısmpo "liver" (article "ятра" in [5]), Pol. jątrznica, Polab. jọtra "liver", jotrenéica "liver sausage", further on to Russ. я́mpa "insides", ятро "liver", etc.;

b) ${ }^{*} \boldsymbol{y}^{V} \boldsymbol{r}$ - $>*(w) V N t^{V_{r-}}>$ OInd. antrám "insides", ántaras, Avest. antara-, Lat. interior "inner", venter "belly" (with irregular labialization), AGr. हैv $\tau \varepsilon \rho o v$ "insides, womb";

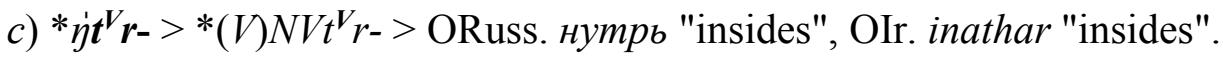




\section{Lexemes related to Russ. неясыть.}

The origin of related forms неясыть "a kind of owl" (from ORuss. нендсыть "a fabulous insatiable bird; a kind of owl; pelican" [21] and ненасытный "insatiable" results from splitting of the same PIE preposition / prefix * $(w / j) \dot{\eta}->\{n a-; j a-\}-$ the reflexes $c)$ and $d)$.

Lexemes related to Russ. уж, угорь, нагой:

$a)^{*}[\mathrm{j}]>*[(\mathrm{w}) \mathrm{g}] /{ }^{*}[(\mathrm{w}) \mathrm{e}]: *(w) e \gamma^{-/ *}(w) e \gamma^{-}>$Pol. wąz, gen. węża "water snake"; OCS жгорищь, Pol. węgorz "eel"; further on to ORuss. ужь, Serb. ÿгор, etc.;

b) *[门] $>*[\mathrm{VN}]:{ }^{*} \boldsymbol{V} N_{\gamma}->$ Lat. anguis "snake", OPruss. angis "snake", Lith. angis "snake, water snake"; AGr. ह̋ $\gamma \chi \varepsilon \lambda v \varsigma$ "eel", OPruss. angurgis, Lith. ungurys, OHG unc "water snake", OIr. escung "eel" (literally, esc-ung "water snake", article "yж" in [5]);

c) $*[\dot{\mathfrak{y}}]>*\left[{ }^{(\mathrm{V})} \mathrm{NV}\right]:{ }^{*} N V_{\gamma^{-}}>$OInd. nāgas, OE snaca; OInd. nagnás, Avest. mayna-, OIr. nocht, OE nacod "naked", OCS нагъ "naked" (article "нагой" in [5]);

d) *[门่] $>*[\mathrm{~V}]: * V \gamma_{-}>$Lett. ùodzs, uôdze "viper" (article "yж" in [5]); some dictionaries add

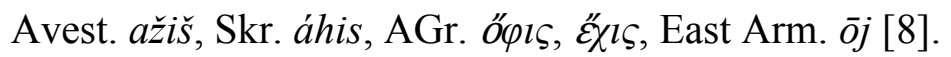

Lexemes related to Russ. нога, ноготь:

b) *[门்] > [VN]: * $V^{\eta} g^{h_{-}}>$OInd. áṅghri- "foot", Lat. unguis, OIr. ingen "fingernail";

c) $*[\mathrm{j}]>$ [(V)NV]: *(V) $\eta^{V} \boldsymbol{g}^{\boldsymbol{h}_{-}}>$Tokh. A maku, B mekwa (Russian meaning: ноготь [4]), OInd. nakhá-, N. Pers. nāxun "finger/toe nail, claw", OHG nagal "fingernail", OCS нога "leg", ногъть "fingernail", OPruss. nage "foot", Lith. nãgas "fingernail", nagà "hoof", Lett. nagas "limbs", AGr. ôv $v \xi$ "fingernail", Arm. ufuqh $h_{L}$ [magil];

d) $*[\dot{\mathrm{j}}]>[\mathrm{V}]: * \boldsymbol{*} \boldsymbol{g h}->$ OCymr. eguin.

Initial $[\mathrm{m}]$ in Tokharian and Armenian lexemes results from splitting $*[\mathrm{n}]>\{\mathrm{n}, \mathrm{m}\}$, as well as [m] in the above mentioned Avest. mayna- "naked" and OHG dial. fimf "five".

One could ask if there are examples with the reflex $a$ ), i. e. with an initial nasal vowel. We could not find any with meanings "leg" or "fingernail". But the prototype ${ }^{*} V^{\eta} \mathbf{g}^{h}$ - extended by $-l$ could be the source for OCS жгъль "angle".

Sorbian lexemes with the meaning "angle" to some extent confirm this suggestion having initial [nu] instead of expected [u], [wu] or [hu], the latter being registered, e. g., in Lower Sorbian huśica "duck": Upper Sorbian nuht, Lower Sorbian nuget (compare Upper Sorbian noha, Lower Sorbian noga, both meaning "leg"). This can shed light on the semantics of the notion of angle: an angle is a figure similar to the shape of a bent leg or a figure formed by legs making a step.

Conclusion. VNT combinations proved to be the most certain, observable in the majority of IE languages. Being widely spread, $V N T$ combinations lead to the belief that they coincide with PIE prototypes.

A comparative analysis of IE lexemes, containing combinations * $V N T$ of nasal consonants with vowels before a consonant, has revealed some regularities in the evolution of such combinations common for IE languages.

Evolution of combinations of vowels and nasal consonants succeeded by consonants, most probably, had begun from ${ }^{*} \dot{\eta} T$, where the syllable velar nasal consonant gradually evolved to nasal vowels and further on to combinations of vowels and nasal consonants: $V N$ или $(V) N V$.

Divergence of the PIE velar nasal was a live process in IE languages even after their separation from each other, consider related OInd. ánghri- "foot" and nakhá- "fingernail", áhis and nāgas "snake" and related Lith. lexemes. 
The offered choice of PIE syllable velar nasal consonant * $[\dot{y}]$ instead of traditional $*[n]$ and *[m] permits:

- to suggest new PIE prototypes: * $\dot{\eta}$ t- "duck", * $y^{\prime} b^{h}$ - "sharp edge / tooth", *p $\dot{\eta} k^{n}$ "five",

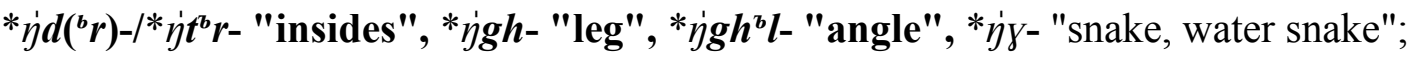

- to explain $[\mathrm{n}] \sim[\mathrm{m}]$ oscillations in related IE lexemes;

- to clarify the historical relations between ${ }^{*} V N T$ and ${ }^{*} q T /{ }^{*} e T$ combinations;

- to clear out some new etymological relations, e.g. between Lat. nutrire and Russ. нympo, both being lexemes with a prefix $* n u-<*(w) \dot{\eta}$ - (the reflex $c)$ ) [22].

\section{REFERENCES}

1. Bernshtein, S.B. (2005), Sravnitel'naya grammatika slavyanskikh yazykov [Comparative grammar of slavic languages], 2nd ed., MGU, Nauka, Moscow, Russia.

2. Ancient Greek-Russian dictionary by I. H. Dvoreckiy, available at: https://classes.ru/allgreek/dictionary-greek-russian-old.htm (accessed 17.08.2019).

3. Slovari na IRISTON.COM [Dictionaries on IRISTON.COM], available at: http://slovar.iriston.com (accessed 17.08.2019).

4. Indo-European etymology, available at: http://starling.rinet.ru/cgi-bin/query.cgi?basename=I datalielpiet\&root $=$ config\&morpho $=0$ (accessed 17.08.2019).

5. Vasmer, M. (1986), Russisches etymologisches Wörterbuch, in Larin, B.A. (ed.), Transl. by Trubachev, O.N., in 4 vol., 2nd ed., Progress, Moscow, Russia, available at: http://etymolog.ruslang.ru/ index.php?act=contents\&book=vasmer (accessed 17.08.2019).

6. Dicționare ale limbii române (2019), available at: https://dexonline.ro (accessed 17.08.2019).

7. Harper, D. Online Etymology Dictionary, available at: http://www.etymonline.com/ (accessed 08.2019).

8. Indo-European Lexical Cognacy Database (LexDB version 0.9), available at: http://ielex.mpi.nl/ wordlist/all/ (accessed 17.08.2019).

9. Wiktionary, available at: https://en.wiktionary.org/wiki/Wiktionary:Main_Page (accessed 17.08.2019).

10. Recasens, D. (2013), "On the articulatory classification of (alveolo)palatal consonants", Journal of the International Phonetic Association, vol. 43, no. 1, pp. 1-22.

11. Telezhko, G.M. (2016), "On the divergence of palatal lateral approximant in Slavic languages", Universum: filologiya i iskusstvovedenie, no. 12 (34), available at: http://7universum.com/ru/philology/archive/ item/4029 (accessed 17.08.2019).

12. Telezhko, G.M. (2017), "On the divergence of a voiced velarized lateral approximant in indoeuropean languages", Success of modern science and education, vol. 3, no. 1, pp. 100-102.

13. Telezhko, G.M. (2017), "Combinations of liquid consonants with vowels in the roots of words in languages of the indo-european family", Universum: filologiya $i$ iskusstvovedenie, no. 12 (34), available at: http://7universum.com/ru/philology/archive/item/4076 (accessed 17.08.2019).

14. Galinskaya, E.A. (1993), O khronologii nekotorykh izmenenii v sisteme vokalizma praslavyanskogo yazyka [On the chronology of some changes in the system of vocalism of the proto-Slavic language], available at: https://www.academia.edu/38029611/ (accessed 17.08.2019).

15. Meillet A. (2001), Le Slave Commun, in Bernshtein, S.B. (ed.), Transl. by Vain, A. and Kuznetsov, P.S. 2nd ed., Progress, Moscow, Russia.

16. Toshovich, B. (2011), Korrelyatsionnaya grammatika serbskogo, khorvatskogo i boshnyatskogo yazykov [Correlation Grammar of Serbian, Croatian and Bosnian], vol. 1, Part 1: Phonetics Linguistics - Prosody, Languages of Slavic Culture, Moscow, Russia.

17. Florinskii, T. (1895), Lektsii po slavyanskomu yazykoznaniyu [Lectures on Slavic linguistics], vol. 1, Tipografiya Imperatorskogo Universiteta sv. Vladimira, Kiev, Rossiiskaya imperiya.

18. Moravcsik, G. (1967), Constantine Porphyrogenitus. De administrando imperio, in Moravcsik, G. (ed.), Transl. by Jenkins, R.J.H. Dumbarton Oaks, Washington, USA. 
19. Meillet, A. (1903), Introduction à l'étude comparative des langues indo-européennes, Librairie Hachette et Cie, Paris, FRA.

20. Telezhko, G.M. (2019), "Evolution of an archaic morpheme with the semantics of possession", Universum: filologiya $i$ iskusstvovedenie, no. 4 (61), available at: http://7universum.com/ru/philology/ archive/item/7120 (accessed 17.08.2019).

21. Dal, V.I. (1863-1866), Tolkovyi slovar' [Dahl's explanatory dictionary], available at: http://dic.academic.ru/contents.nsf/enc2p (accessed 17.08.2019).

22. Telezhko, G.M. (2017), "On the divergence of proto-indo-european syllabic nasals in indoeuropean languages", Universum: filologiya i iskusstvovedenie, no. 1(35), available at: http://7universum.com/ ru/philology/archive/item/4178 (accessed 17.08.2019).

\section{Information about the author.}

Georgiy M. Telezhko - Can. Sci. (Engineering) (1997), Director of IP "Georgiy Mikhailovich Telezhko", 167-8 Fontanka riv. emb., St Petersburg 190121, Russia. The author of 46 scientific publications. Areas of expertise: comparative linguistics, atmospheric physics, relativity theory. Email: yurate@bk.ru

\section{СПИСОК ЛИТЕРАТУРЫ}

1. Бернштейн С. Б. Сравнительная грамматика славянских языков: учеб. 2-е изд. / МГУ. М.: Наука, 2005.

2. Древнегреческо-русский словарь И. Х. Дворецкого. URL: https://classes.ru/all-greek/dictionary-greek-russian-old.htm (дата обращения: 17.08.2019).

3. Словари на IRISTON.COM. URL: http://slovar.iriston.com (дата обращения: 17.08.2019).

4. Indo-European etymology. URL: http://starling.rinet.ru/cgi-bin/query.cgi?basename=ldataliel piet\&root=config\&morpho=0 (дата обращения: 17.08.2019).

5. Фасмер М. В. Этимологический словарь русского языка: в 4 т. / пер. О. Н. Трубачева; под ред. Б. А. Ларина. 2-е изд. М.: Прогресс, 1986. URL: http://etymolog.ruslang.ru/index.php?act=contents\&book =vasmer (дата обращения: 17.08.2019).

6. Dicționare ale limbii române. URL: https://dexonline.ro (дата обращения: 17.08.2019).

7. Harper D. Online Etymology Dictionary. URL: http://www.etymonline.com/ (дата обращения: 17.08.2019).

8. Indo-European Lexical Cognacy Database (LexDB version 0.9). URL: http://ielex.mpi.nl/wordlist/all/ (дата обращения: 17.08.2019).

9. Wiktionary. URL: https://en.wiktionary.org/wiki/Wiktionary:Main_Page (дата обращения: 17.08.2019).

10. Recasens D. On the Articulatory Classification of (Alveolo)palatal Consonants // Journal of the International Phonetic Association. 2013. Vol. 43, no 1. P. 1-22.

11. Тележко Г. М. О дивергенции палатального бокового аппроксиманта в славянских языках // Universum: Филология и искусствоведение. 2016. № 12 (34). URL: http://7universum.com/ ru/philology/archive/item/4029 (дата обращения: 17.08.2019).

12. Тележко Г. М. О дивергенции звонкого веляризованного бокового аппроксиманта в индоевропейских языках // Успехи современной науки и образования. 2017. Т. 3, № 1. С. 100-102.

13. Тележко Г. М. Сочетания плавных согласных с гласными в корнях слов языков индоевропейской семьи // Universum: Филология и искусствоведение. 2017. № 1 (35). URL: http://7universum.com/ru/philology/archive/item/4076 (дата обращения: 17.08.2019).

14. Галинская Е. А. О хронологии некоторых изменений в системе вокализма праславянского языка. URL: https://www.academia.edu/38029611/ (дата обращения: 17.08.2019).

15. Мейе А. Общеславянский язык / пер. А. Вайна, П. С. Кузнецова; общ. ред. С. Б. Бернштейна. 2-е изд., М.: Прогресс, 2001. 
16. Тошович Б. Корреляционная грамматика сербского, хорватского и бошняцкого языков. Т. 1. Ч. 1. Фонетика - Фонология - Просодия. М.: Языки славянской культуры, 2011.

17. Флоринский Т. Лекции по славянскому языкознанию. Ч. 1. Киев: Тип. Имп. ун-та св. Владимира, 1895.

18. Constantine Porphyrogenitus. De administrando imperio / in G. Moravcsik (ed.), transl. by R. J. H. Jenkins. Washington: Dumbarton Oaks, 1967.

19. Meillet A. Introduction à l'étude comparative des langues indo-européennes. Paris: Librairie Hachette et Cie, 1903.

20. Тележко Г. М. Эволюция одной архаичной морфемы с семантикой принадлежности // Universum: Филология и искусствоведение. 2019. № 4(61). URL: http://7universum.com/ru/philology/ archive/item/7120 (дата обращения: 17.08.2019).

21. Даль В. И. Толковый словарь. 1863-1866. URL: http://dic.academic.ru/contents.nsf/enc2p (дата обращения: 17.08.2019).

22. Тележко Г. М. О дивергенции праиндоевропейских слоговых носовых согласных в индоевропейских языках // Universum: Филология и искусствоведение. 2017. № 1 (35). URL: http://7universum.com/ru/philology/archive/item/4178 (дата обращения: 17.08.2019).

\section{Информация об авторе.}

Тележко Георгий Михайлович - кандидат технических наук (1997), ИП «Георгий Михайлович Тележко», наб. р. Фонтанки, д. 167, кв. 8, Санкт-Петербург, 190121, Россия. Автор 46 научных публикаций. Сфера научных интересов: сравнительное языкознание, физика атмосферы, теория относительности. E-mail: yurate@bk.ru 